\title{
Morphometric measurements of the European pond turtle (Emys orbicularis) (L., 1758) in Lithuania
}

\author{
Karolina Lukošiūtè ${ }^{1}$, \\ Monika Brimaité丶 \\ Alma Pikūnienè2, \\ Ramūnas Krugelis ${ }^{3}$
Algimantas Paulauskas ${ }^{1 \star}$
${ }^{1}$ Vytautas Magnus University, Universiteto St. 10, Akademija 53361, Kaunas district, Lithuania \\ ${ }^{2}$ Lithuanian Zoo, Radvilènų St. 21, \\ Kaunas 50299, Lithuania \\ ${ }^{3}$ Meteliai Regional Park Directorate, \\ Seiriju St. 2, Meteliai 67482, \\ Lazdiju district, Lithuania
}

\begin{abstract}
In Lithuania, the number of European pond turtles Emys orbicularis decreased between 1975 and 2010, but increased significantly between 2010 and 2014, when the LIFE project was implemented. During this project, an ecological network was created, habitats were restored in protected areas, and European pond turtle nesting areas were protected from predators. Very few morphometric measurements of European pond turtles are carried out in Lithuania. The purpose of this study was to perform morphometric measurements, assess migration, spread, and morphometric size variation. Morphometric measurements of juvenile European pond turtles showed that the morphometric indicators depended on the place of habitation: males from Juodabale Zoological Reserve (Meteliai Regional Park) are smaller than females. Also, female turtles from Meteliai Regional Park are larger than both males and females from Kučiuliškè Herpetological Reserve. When comparing the morphometric indicators of males and females at ten months of age, sexual dimorphism is already observed: the shell height, the width of the head, carapace, and plastron of a females are already bigger than those of males.
\end{abstract}

Keywords: Emys orbicularis, European pond turtles, juveniles, morphometrics, Lithuania

\section{INTRODUCTION}

European pond turtles Emys orbicularis (L., 1758) are protected in all European countries, most of which classify them as an endangered species threatened with extinction (Rivera, Fer-

\footnotetext{
*Corresponding author. Email: algimantas.paulauskas@vdu.lt
}

nandez, 2004; Sommer et al., 2007; Fritz et al., 2009; Prusak et al., 2011; Rakauskas et al., 2016). In Lithuania, the number of European pond turtles decreased between 1975 and 2010, but has increased significantly since 2010, when the LIFE project was implemented between 2010 and 2014. During this project, an ecological network was created, habitats were restored in protected areas, and nesting areas of the European 
pond turtle were protected from predators (Ruzauskas et al., 2016). One of the reasons for the successful recreation of European pond turtles was the implementation of a conservation programme: the turtles were taken from nature to the Lithuanian Zoological Gardens in Kaunas where all necessary help was provided to strengthen them; a year later, the juveniles were released back into nature (Ruzauskas et al., 2016). From 2017 to 2021, the project 'Implementation of Nature Conservation and Management Measures by Preserving and Increasing the Populations of European Pond Turtles and European Fire-bellied Toad' was implemented by closely working with the Lithuanian Zoological Gardens in an attempt to conserve as many European pond turtles as possible. The aim of the project was to increase the population of European pond turtles by breeding and habitat management. It is planned to increase the population of European pond turtles by raising and releasing at least 300 juveniles by October 2021 .

However, there are very few morphometric measurements of European pond turtles in Lithuania. One of the measurements was taken by Meeske et al. $(1997,2006)$ in Kučiuliške Herpetological Reserve in Meteliai Regional Park. Female turtles, their eggs, and their nests (Meeske, 1997) were measured during the study. No significant evidence was found between the body size of the female and the number of eggs in the laying, but some studies suggest that the larger the female, the more eggs are found (Meeske, 1997). Other measurements of European pond turtles involved newly hatched turtles and adults when examining the impact of invasive species on the Emys orbicularis in August 2015 (Rakauskas et al., 2016). Morphometric measurements of juveniles have not been conducted in Lithuania. The purpose of our study was to perform morphometric measurements, assess migration, spread, and morphometric size variation. The study presents 2020 data on the morphologic size of the juveniles of this population and the relationship with the population spread. These results should facilitate a better understanding of European pond turtles and their distribution in Lithuania.

\section{MATERIALS AND METHODS}

The study was conducted in southern Lithuania at the end of May 2020. The main study area was the Herpetological Reservation Kučiuliškė and Juodabalès zoological reserve. During the project 'Implementation of Nature Conservation and Management Measures by Preserving and Increasing the Populations of European Pond Turtles and European Fire-bellied Toad' aimed at protection of the European pond turtle (Nr. 05.4.1-APVA-V-018-01-0004) of 2017-2021, the juveniles were measured at the time when they were kept at the Lithuanian Zoological Gardens. Morphometric measurements were performed on 25 ten-monthold juveniles from two different locations in Lithuania.

The morphometric measurements technique taken from Fritz and Obst (1995) was as follows: (1) shell height (this was taken as the vertical line through the highest point to the base of the plastron) ( $\mathrm{PH}),(2)$ head width (KB), (3) straight carapace length (CL), (4) carapace width (CB), (5) plastron length (PL), (6) plastron width (among HumL and GuL) (PBI), and (7) plastron width (among FemL and AbdL) (PBII) (Fig. 1).

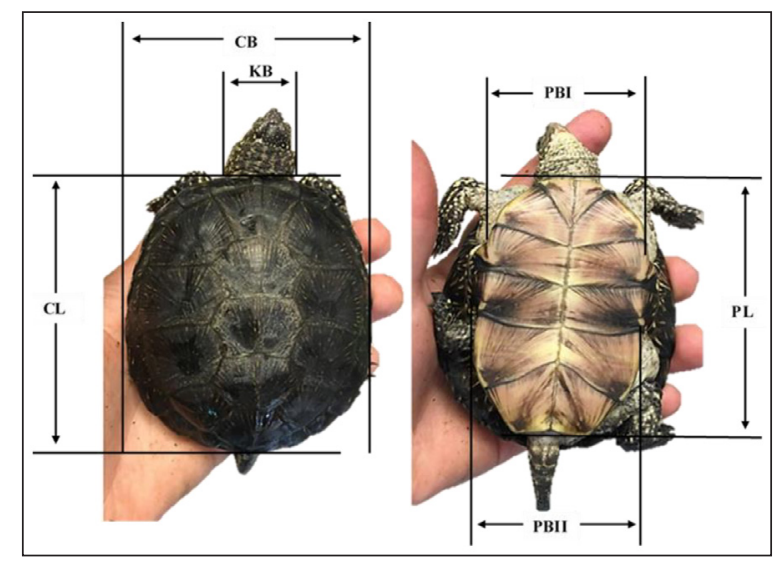

Fig. 1. Principle of measuring European pond turtles 
After measurement, each turtle was weighed with laboratory scales and photographed from carapax and plastron sides (Fig. 2). All collected data was processed in Microsoft Excel.
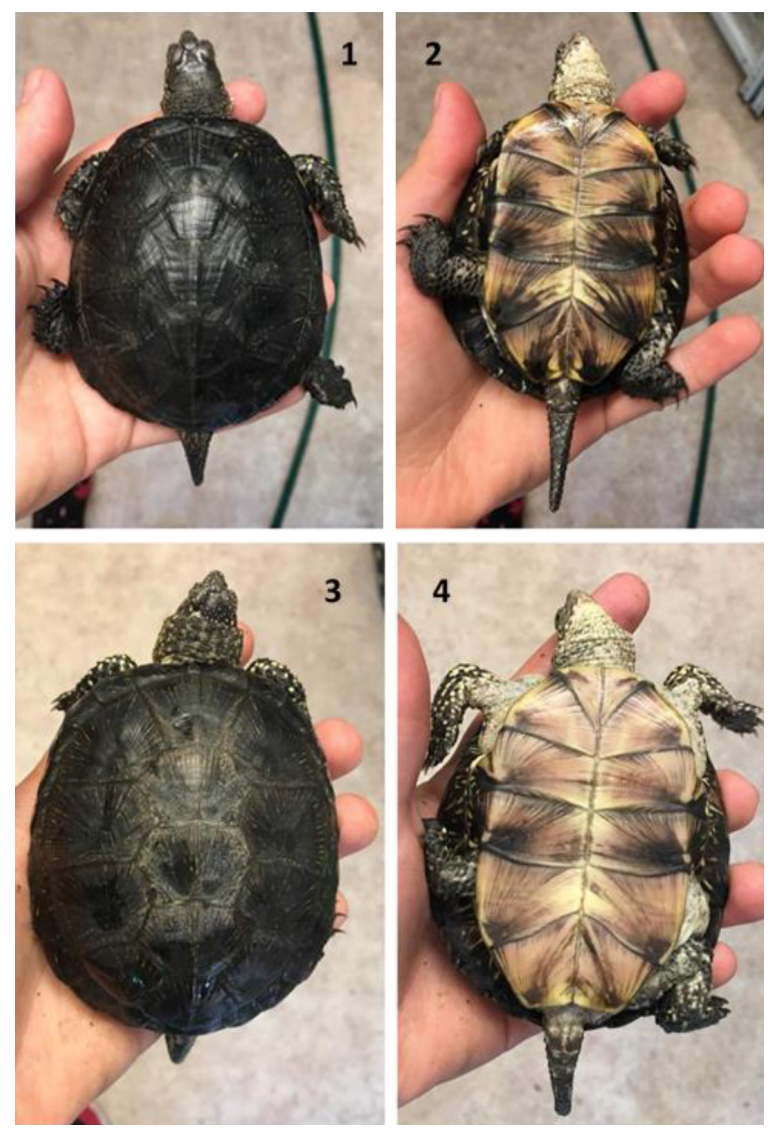

Fig. 2. Male dorsal (1) and ventral (2) sides; female dorsal (3) and ventral (4) sides of juvenile European pond turtles from Kučiuliške Herpetological Reserve
The minimum and maximum dimensions and the average were determined by the location and sex of European pond turtles. Collected data was used for the statistical analysis (t-test).

\section{RESULTS AND DISCUSSION}

Morphometric measurements were performed on the juveniles from Juodabale Zoological Reserve. Measurements for males and females are presented separately in Tables 1 and 2 .

The weight of males correlated from $50.1 \mathrm{~g}$ to $100.4 \mathrm{~g}$ and of females from $71.90 \mathrm{~g}$ to $116 \mathrm{~g}$.

Comparison of the overall results of the measurements of twelve individuals from Juodabale showed that ten-month-old females were larger in all dimensions than males of the same age.

The juveniles from Kučiuliške Herpetological Reserve were also measured (Tables 3 and 4).

The heavy weight of the males was observed, with the heaviest male weighing $203.90 \mathrm{~g}$.

Comparison of the measurements of the females and males from Kučiuliške showed that males weighed more than females, although sexual dimorphism is characteristic of European pond turtles: males are usually smaller than females (Zuffi et al., 1999).

These results suggest that males from the Juodabale Zoological Reserve (Meteliai Regional Park) are smaller and the females

Table 1. Data of ten-month-old males of the Juodabalè Zoological Reserve

\begin{tabular}{c|c|c|c|c|c|c|c|c}
\hline & & & \multicolumn{2}{|c|}{ Carapax } & \multicolumn{3}{c|}{ Plastron } & \\
\hline $\begin{array}{c}\text { Sex } \\
\text { Male }\end{array}$ & $\begin{array}{c}\text { PH } \\
(\mathrm{mm})\end{array}$ & $\begin{array}{c}\text { KB } \\
(\mathrm{mm})\end{array}$ & $\begin{array}{c}\text { CL } \\
(\mathrm{mm})\end{array}$ & $\begin{array}{c}\text { CB } \\
\mathbf{m m})\end{array}$ & $\begin{array}{c}\text { PL } \\
(\mathrm{mm})\end{array}$ & $\begin{array}{c}\text { PBI } \\
(\mathrm{mm})\end{array}$ & $\begin{array}{c}\text { PBII } \\
(\mathrm{mm})\end{array}$ & $\begin{array}{c}\text { Weight } \\
(\mathrm{g})\end{array}$ \\
\hline 1. & 50.4 & 36.91 & 89 & 81.02 & 83.44 & 59.06 & 59.72 & 50.1 \\
\hline 2. & 53.47 & 40.41 & 103.09 & 95.58 & 93.44 & 67.4 & 70.34 & 87.1 \\
\hline 3. & 54.91 & 40.98 & 99.6 & 90.87 & 94.82 & 67.64 & 68.89 & 64.3 \\
\hline 4. & 66 & 51.78 & 117.83 & 106.16 & 111.52 & 78.87 & 79.92 & 100.4 \\
\hline Min & 50.40 & 36.91 & 89.00 & 81.02 & 83.44 & 59.06 & 59.72 & 50.10 \\
\hline Max & 66.00 & 51.78 & 117.83 & 106.16 & 111.52 & 78.87 & 79.92 & 100.40 \\
\hline Average & 56.20 & 42.52 & 102.38 & 93.41 & 95.81 & 68.24 & 69.72 & 75.48 \\
\hline
\end{tabular}


Table 2. Data of ten-month-old females of the Juodabalè Zoological Reserve

\begin{tabular}{c|c|c|c|c|c|c|c|c}
\hline & & & \multicolumn{2}{c|}{ Carapax } & \multicolumn{3}{c}{ Plastron } & CB \\
\hline $\begin{array}{c}\text { Sex } \\
\text { Female }\end{array}$ & $\begin{array}{c}\text { PH } \\
(\mathbf{m m})\end{array}$ & $\begin{array}{c}\text { KB } \\
(\mathbf{m m})\end{array}$ & $\begin{array}{c}\text { CL } \\
(\mathbf{m m})\end{array}$ & $\begin{array}{c}\text { PL } \\
(\mathbf{m m})\end{array}$ & $\begin{array}{c}\text { PBI } \\
(\mathbf{m m})\end{array}$ & $\begin{array}{c}\text { PBII } \\
(\mathbf{m m})\end{array}$ & $\begin{array}{c}\text { Weight } \\
(\mathbf{m m})\end{array}$ \\
\hline 1. & 63.7 & 48.34 & 118.75 & 107.91 & 110.54 & 79.11 & 80.86 & 116 \\
\hline 2. & 62.53 & 50.42 & 108.82 & 95.63 & 101.33 & 73.39 & 74.28 & 71.9 \\
\hline 3. & 68.89 & 52.94 & 113.01 & 102.5 & 108.98 & 78.79 & 79.98 & 93.7 \\
\hline 4. & 66.45 & 52.58 & 114.79 & 104.2 & 107.59 & 79.2 & 79.49 & 94.9 \\
\hline 5. & 68.9 & 53.11 & 118.06 & 106.45 & 112.56 & 79.93 & 81.83 & 110 \\
\hline 6. & 69.8 & 51.39 & 115.94 & 107.55 & 110.32 & 80.05 & 82.88 & 114.6 \\
\hline 7. & 65.95 & 48.8 & 116.05 & 105.43 & 110.27 & 76.76 & 80.44 & 100.4 \\
\hline 8. & 66.08 & 51.62 & 114.49 & 103.25 & 106.89 & 77.9 & 79.51 & 92.8 \\
\hline Min & 62.53 & 48.34 & 108.82 & 95.63 & 101.33 & 73.39 & 74.28 & 71.90 \\
\hline Max & 69.80 & 53.11 & 118.75 & 107.91 & 112.56 & 80.05 & 82.88 & 116.00 \\
\hline Average & 66.54 & 51.15 & 114.99 & 104.12 & 108.56 & 78.14 & 79.91 & 99.29 \\
\hline
\end{tabular}

Table 3. Data on ten-month-old males from Kučiuliškẻ Herpetological Reserve

\begin{tabular}{|c|c|c|c|c|c|c|c|c|}
\hline \multirow[b]{2}{*}{$\begin{array}{c}\text { Sex } \\
\text { Male }\end{array}$} & \multirow[b]{2}{*}{$\begin{array}{c}\mathrm{PH} \\
(\mathrm{mm})\end{array}$} & \multirow[b]{2}{*}{$\begin{array}{c}\mathrm{KB} \\
(\mathrm{mm})\end{array}$} & \multicolumn{2}{|c|}{ Carapax } & \multicolumn{3}{|c|}{ Plastron } & \multirow[b]{2}{*}{$\begin{array}{c}\text { Weight } \\
\text { (g) }\end{array}$} \\
\hline & & & $\begin{array}{c}\mathrm{CL} \\
(\mathrm{mm})\end{array}$ & $\begin{array}{c}\mathrm{CB} \\
(\mathrm{mm})\end{array}$ & $\begin{array}{c}\mathrm{PL} \\
(\mathrm{mm})\end{array}$ & $\begin{array}{c}\text { PBI } \\
(\mathrm{mm})\end{array}$ & $\begin{array}{l}\text { PBII } \\
(\mathrm{mm})\end{array}$ & \\
\hline 1. & 43.3 & 21.49 & 103.06 & 88.53 & 96.21 & 50.12 & 55.64 & 203.9 \\
\hline 2. & 38.46 & 24.64 & 102.6 & 85.38 & 91.93 & 46.75 & 53.35 & 187.5 \\
\hline 3. & 37.51 & 19.7 & 102.05 & 85.4 & 91.53 & 53.02 & 60.58 & 188.3 \\
\hline 4. & 43.41 & 25.95 & 101.31 & 89.2 & 92.73 & 60.75 & 60.62 & 149.8 \\
\hline 5. & 47.4 & 28 & 108.56 & 94.11 & 98.83 & 66.24 & 67.37 & 151.7 \\
\hline 6. & 50.1 & 34.79 & 106.13 & 95.41 & 98.78 & 61.1 & 64.23 & 141.6 \\
\hline 7. & 55.37 & 43.68 & 102.2 & 92.95 & 92.36 & 67.89 & 68.63 & 85.9 \\
\hline Min & 37.51 & 19.70 & 101.31 & 85.38 & 91.53 & 46.75 & 53.35 & 85.90 \\
\hline $\operatorname{Max}$ & 55.37 & 43.68 & 108.56 & 95.41 & 98.83 & 67.89 & 68.63 & 203.90 \\
\hline Average & 45.08 & 28.32 & 103.70 & 90.14 & 94.62 & 57.98 & 61.49 & 158.39 \\
\hline
\end{tabular}

Table 4. Data on ten-month-old females from Kučiuliškẻ Herpetological Reserve

\begin{tabular}{c|c|c|c|c|c|c|c|c}
\hline & & \multicolumn{2}{|c|}{ Carapax } & \multicolumn{3}{c}{ Plastron } & \\
\hline $\begin{array}{c}\text { Sex } \\
\text { Female }\end{array}$ & $\begin{array}{c}\text { PH } \\
(\mathrm{mm})\end{array}$ & $\begin{array}{c}\text { KB } \\
(\mathrm{mm})\end{array}$ & $\begin{array}{c}\mathrm{CL} \\
(\mathrm{mm})\end{array}$ & $\begin{array}{c}\mathrm{CB} \\
(\mathrm{mm})\end{array}$ & $\begin{array}{c}\text { PL } \\
(\mathrm{mm})\end{array}$ & $\begin{array}{c}\text { PBI } \\
(\mathrm{mm})\end{array}$ & $\begin{array}{c}\text { PBII } \\
(\mathrm{mm})\end{array}$ & $\begin{array}{c}\text { Weight } \\
(\mathrm{g})\end{array}$ \\
\hline 1. & 34.09 & 17.88 & 86.19 & 72.72 & 78.05 & 45.75 & 48.62 & 118 \\
\hline 2. & 43.09 & 24.74 & 101.8 & 88.36 & 93.17 & 56.2 & 58.6 & 173.3 \\
\hline 3. & 52.26 & 34.37 & 104.46 & 93 & 95.07 & 64.7 & 65.47 & 135.9 \\
\hline 4. & 51.45 & 38.96 & 118.31 & 102.53 & 111.47 & 77.08 & 78.13 & 153.3 \\
\hline 5. & 63.42 & 45.02 & 126 & 109.81 & 117.7 & 79.61 & 82.41 & 187.6 \\
\hline 6. & 55.89 & 43.05 & 106.72 & 96.36 & 98.59 & 68.18 & 68.7 & 105.2 \\
\hline Min & 34.09 & 17.88 & 86.19 & 72.72 & 78.05 & 45.75 & 48.62 & 105.20 \\
\hline Max & 63.42 & 45.02 & 126.00 & 109.81 & 117.70 & 79.61 & 82.41 & 187.60 \\
\hline Average & 50.03 & 34.00 & 107.25 & 93.80 & 99.01 & 65.25 & 66.99 & 145.55 \\
\hline
\end{tabular}


are larger than the females and males from the Kučiuliške Herpetological Reserve (Fig. 3).

There is a noticeable size difference between Emys orbicularis from different habitats, which suggests that one of the factors influencing turtle sizes is the difference in environment (habitat). The importance of different habitats for the size of European pond turtles was also emphasized by Eniko Horvath et al. (2020) in their study investigating carapace anomalies. The authors emphasise that factors such as resource availability and/or the quality of differ- ent habitat features affect the plasticity of turtle shell shapes. However, further research is needed to fully understand the factors affecting size differences. Meeske et al. (2006) mentions large distances between habitats and that this complicates the migration of European pond turtles in Lithuania. Observing migration distances between Lithuania, Poland, and Latvia, we see that these distances between the countries are rather long (Fig. 4). As a result, it could be asserted that migration between countries is impossible.

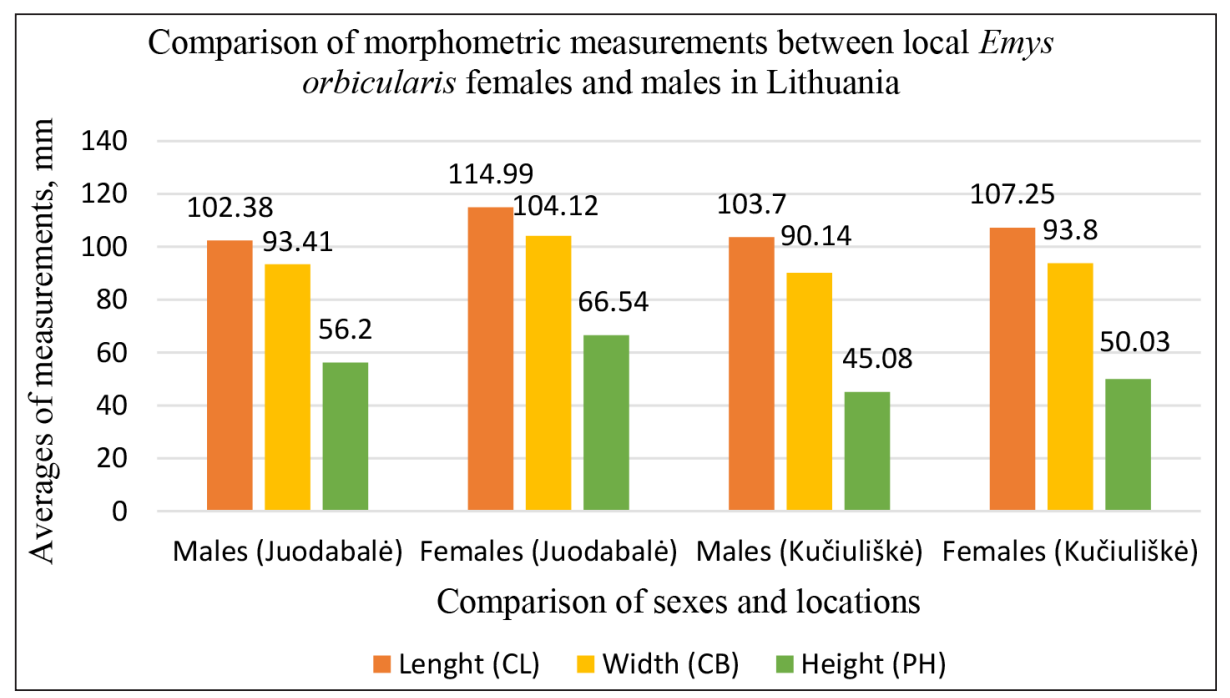

Fig. 3. Comparison of the morphometric measurements of the length $(\mathrm{CL})$, width (CB), and height $(\mathrm{PH})$ between females and males in different areas of Lithuania

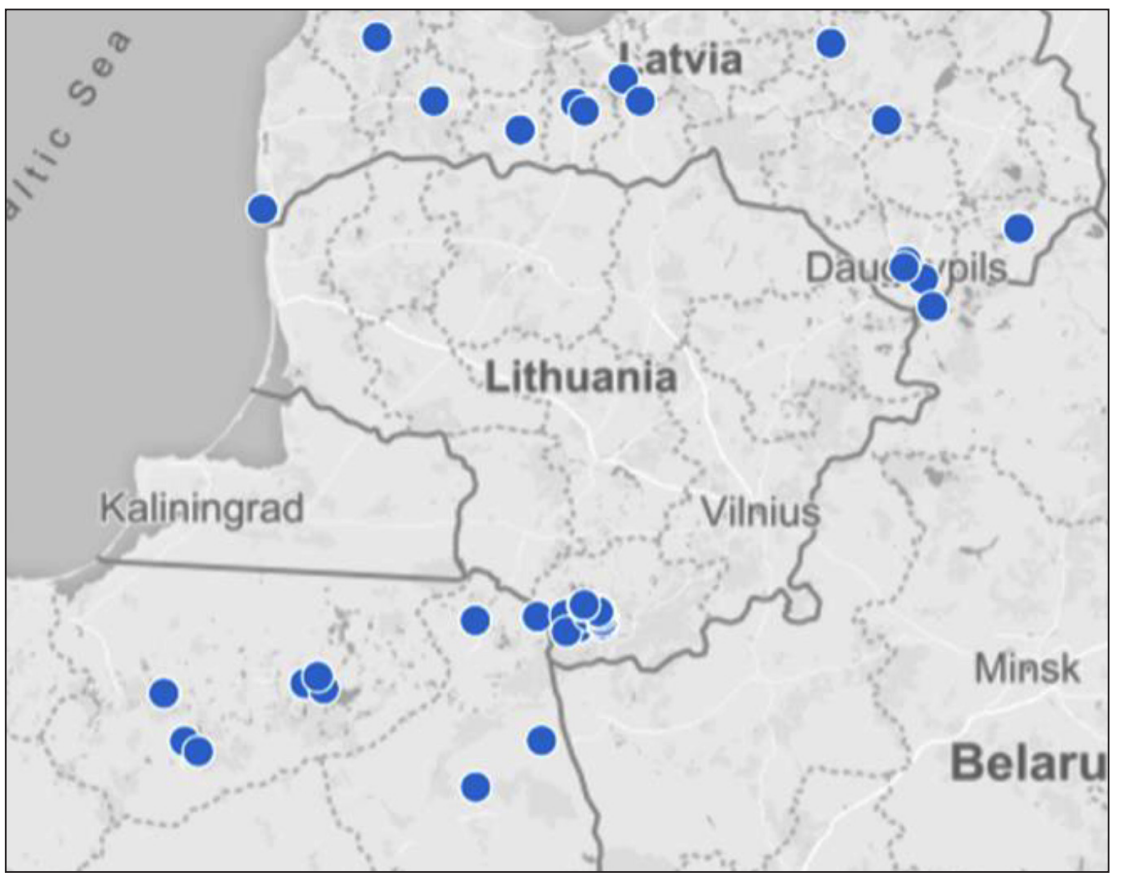

Fig. 4. Prevalence of Emys orbicularis in Lithuania (Lithuanian Red Data Book, 2021), Latvia (Pupins et al., 2017), and Poland (Prusak et al., 2011) 
The morphometric measurements are also performed in other countries, one of them being western Poland (Najbar and Szuszkiewicz, 2006). Individuals were classified as males/females and some year-old individuals were classified as juveniles/subadults and hatchlings. Hatchlings with the carapace length (SCL) between $2.12 \mathrm{~cm}$ and $3.0 \mathrm{~cm}$ constituted $73.1 \%$ of the collected turtles $(n=204)$, juvenile/subadult individuals with SCL between $6.10 \mathrm{~cm}$ and $12.10 \mathrm{~cm}$ came to $5 \%(n=14)$, males with SCL between $13.33 \mathrm{~cm}$ to $18.55 \mathrm{~cm}$ made up $10.1 \%(n=28)$, and females with SCL (length of carapace) between $13.79 \mathrm{~cm}$ and $19.85 \mathrm{~cm}$ amounted to $11.8 \%(n=33)$ (Najbar, Szuszkiewicz, 2006). Comparison of the average length of carapace (CL) of Lithuanian juvenile Emys orbicularis of $102.38 \mathrm{~mm}$ to $114.99 \mathrm{~mm}$ with $610-1210 \mathrm{~mm}$ of the juveniles in western Poland (SCL) showed that European pond turtles in western Poland were bigger. Other morphometric measurements were taken at Lake Tonga (north-eastern Algeria) (Fediras et al., 2017). Sex was determined by secondary sexual characters and the turtles shorter than $12 \mathrm{~cm}$ were considered too small for their sex to be determined and were classified as juveniles. For juveniles, the average carapace length and weight were, respectively, $69.03-110.36 \mathrm{~mm}$ and $88-225 \mathrm{~g}$. The t-test shows statistical $(p<0.0001)$ differences between males and females for all variables (Fediras et al., 2017). Comparison with Lithuanian Emys orbicularis juveniles shows similar results. It is very difficult to compare juveniles of the European pond turtle with other countries due the uncertainty about their exact age. Other studies (Najbar, Szuskiewicz, 2006; Fediras et al., 2017) indicate the age group (juveniles) of pond turtles, while our study defines the exact age. Therefore, comparisons may show large differences in measurement results between juveniles due to the uncertainty about the exact age.

To collate size differences, we compared the morphological measurements of one-yearold European pond turtles (Emys orbicularis) from central Italy (Zuffi et al., 2017) and ten-month-old European pond turtles from Lithuania (Kučiuliške Herpetological Reserve and Juodabale Zoological Reserve), because the age group of the turtles from Italy was the closest to ours. According to the performed t-test, a significant difference was found in the height (PH) of males $(p=0.037101)$ and females $(p=0.00994)$ in Lithuanian juveniles. The carapace growth appeared isometric, since the length and width showed a similar proportional increase (paired t-test: $t=-1.36$ ) of Emys orbicularis in Italy (Fig. 5).

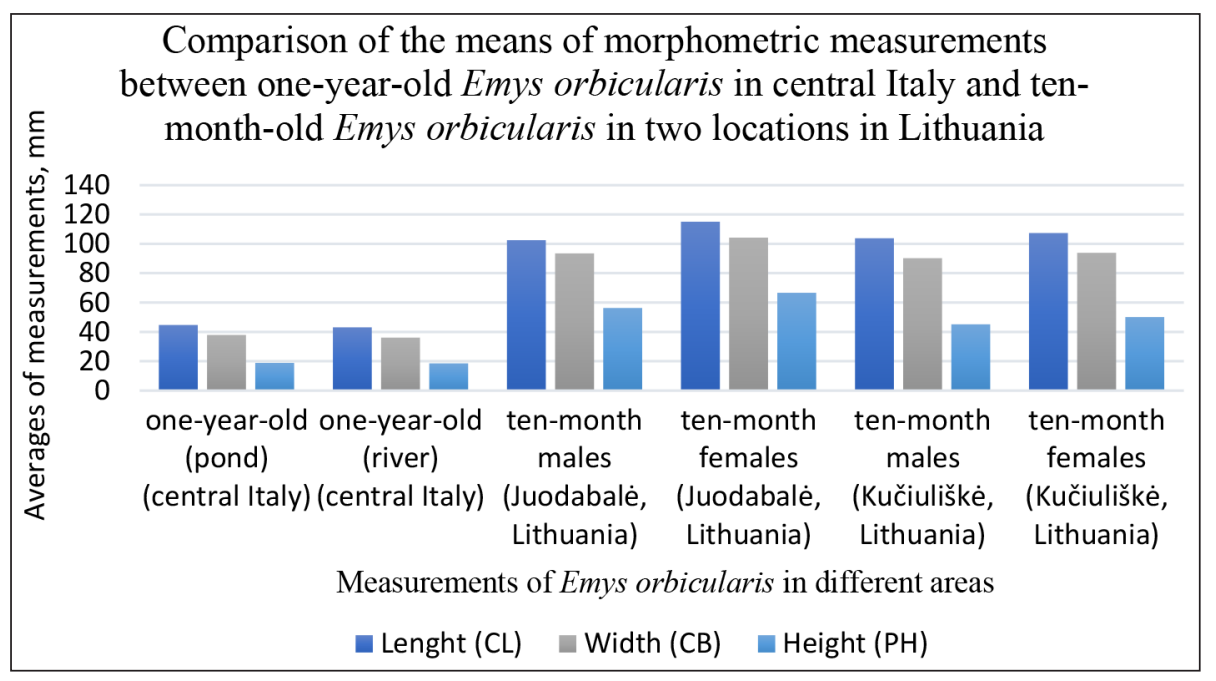

Fig. 5. Comparison of morphometric measurements: averages of the length (CL), width $(\mathrm{CB})$, and height $(\mathrm{PH})$ of one-year-old European pond turtles in central Italy and ten-month-old European pond turtles in two areas in Lithuania 
All measurements correlate with a difference between $26 \mathrm{~mm}$ and $70 \mathrm{~mm}$. Comparison of the results of the measurements strongly suggests that these may be different subspecies of Emys orbicularis, because such large differences in size are not possible between two identical subspecies. The only subspecies Emys orbicularis orbicularis is found in the Eastern European range. Several subspecies, such as E. o. galloitalica and E. o. hellenica, are found in Italy (Lenk et al., 1999). The other factors that can affect differences in size is the genotype, carapace anomalies, or the condition of different habitats (Horvath et al., 2020). Identifying exact causes of the differences in measurements requires further research such as genetic analysis and extensive measurement study.

In the future, it is necessary to continue the conservation project by protecting the species of the European pond turtle in Lithuania. It is important to continue further research, especially into juveniles, to assess their survival and adaptability.

\section{ACKNOWLEDGEMENTS}

Most of all we would like to thank Inga Čitavičienè, chief specialist (ecologist) of Meteliai Regional Park, for her time, insights, and advice. We are grateful to Rasa Jautakiené, chief herpetologist at the Lithuanian Zoological Gardens, for her assistance in morphometric measurements.

Received 30 April 2021

Accepted 28 May 2021

\section{References}

1. Fediras S, Rouag R, Ziane N, Olivier A, Béchet A, Benyacoub S. Population structure and morphometrics of the European pond turtle (Emys orbicularis (Linnaeus, 1758)) at lake Tonga, Algeria. Russ J Herpetol. 2017; 25: 88-96.
2. Fritz U, Obst FJ. Morphologische Variabilität in den Intergradationszonen von Emys orbicularis orbicularis und E. o. hellenica. Salamandra. 1995; 31: 157-80.

3. Fritz U, Ayaz D, Hundsdörfer AK, Kotenko T, Guicking D, Wink M, et al. Mitochondrial diversity of European pond turtles (Emys orbicularis) in Anatolia and the Ponto-Caspian Region: Multiple old refuges, hotspot of extant diversification and critically endangered endemics. Org Divers Evol. 2009; 9: 100-14.

4. Horvath E, Danko S, Havaš P, Schindler M, Šebela M, Halpern B, et al. Variation in shell morphology of the European pond turtle, Emys orbicularis, in fragmented central European populations. Biol J Linn Soc. 2020; 20: 1-14.

5. Lenk P, Fritz U, Joger U, Wink M. Mitochondrial phylogeography of the European pond turtle, Emys orbicularis (Linnaeus 1758). Mol Ecol. 1999; 8: 1911-22.

6. Meeske ACM. Nesting ecology of European pond turtle (Emys orbicularis) in South Lithuania. Acta Zool Litu. 1997; 7: 138-42.

7. Meeske ACM, Pupins M, Rybczynski K. Erste Ergebnisse zur Verbreitung und zum Status der Europäischen Sumpfschildkröte (Emys orbicularis) am nördlichen Rand ihrer Verbreitung in Litauen und Lettland. Z Feldherpetol. 2006; 13: 71-99.

8. Najbar B, Szuszkiewicz E. The morphometrics and colouration of the European pond turtle Emys orbicularis in Lubuskie province (West Poland). Biologia. 2006; 61: 585-92.

9. Prusak B, Najbar B, Mitrus S, Górecki G, Rogalla U, Grzybowski G, et al. Distribution of mitochondrial haplotypes (cytb) in Polish populations of Emys orbicularis (L., 1758). Section Zoology. Biologia. 2011; 66(5): 893-8.

10. Pupins M, Pupina A, Pupina A. Updated distribution of the European pond turtle, Emys orbicularis (L., 1758) (Emydidae) on the Extreme Northern Border of its European Range in Latvia. Acta Zool Bulgarica. 2017; 10: 133-7. 
11. Rakauskas V, Masiulytè R, Pikūnienè A. Predator-prey interactions between a recent invader, the Chinese sleeper (Perccottus glenii) and the European pond turtle (Emys orbicularis): a case study from Lithuania. Acta Herpetol. 2016; 11: 101-9.

12 Red Data Book of Lithuania. 2021; [cited 2021 May 27]. Available from: https://www.raudonojiknyga.lt/atsisiusti-lietuvos-raudonajaknyga-pdf

13. Rivera AC, Fernandenz CA. A management plan for the European pond turtle (Emys orbicularis) populations of the Louro river basin (Northwest Spain). Biologia, Bratislava. 2004; 59(14): 161-71.

14. Ruzauskas M, Misyte S, Vaskeviciute L, Mikniene Z, Siugzdiniene R, Klimiene I, et al. Gut microbiota isolated from the European pond turtle (Emys orbicularis) and its antimicrobial resistance. Pol J Vet Sci. 2016; 19(4): 723-30.

15. Sommer RS, Persson A, Wieseke N, Fritz U. Holocene recolonization and extinction of the pond turtle, Emys orbicularis (L., 1758), in Europe. Quat Sci Rev. 2007; 26: 3099-107.

16. Zuffi MAL, Odetti F, Meozzi P. Body size and clutch size in the European Pond Turtle (Emys orbicularis) from Central Italy. J Zool. 1999; 247: 139-43.

17. Zuffi MAL, Mangiacotti M, Masucci GD. Stable or plastic body shape? Emys orbicularis hatchlings-juveniles growth patterns under different ecological conditions. North-West J Zool. 2017; 13: 262-70.
Karolina Lukošiūtè, Monika Brimaitè, Alma Pikūniené, Ramūnas Krugelis, Algimantas Paulauskas

\section{EUROPINIO BALINIO VĖŽLIO (EMYS ORBI- CULARIS) (L., 1758) MORFOMETRINIAI MATAVIMAI LIETUVOJE}

\section{Santrauka}

Lietuvoje 1975-2010 m. buvo stipriai sumažėjęs europinių balinių věžlių skaičius, tačiau jis labai išaugo 2010-2014 m., kai buvo igyvendintas LIFE projektas. Jo metu buvo sukurtas ekologinis tinklas, atkurtos buveinès saugomose teritorijose, europinių balinių vèžlių lizdavietès pradètos saugoti nuo plèšrūnų. Lietuvoje labai mažai yra atlikta europinių balinių vèžlių morfometrinių matavimų. Šio tyrimo tikslas - atlikti morfometrinius matavimus, įvertinti migraciją, plitimą ir morfometrinių dydžių pakitimus. Atlikus europinių balinių vèžlių jauniklių morfometrinius matavimus pastebèta, kad morfometriniai rodikliai priklauso nuo gyvenamosios vietos: Metelių regioninio parko (Juodabalès zoologinio draustinio) patinai yra mažesni nei patelès, o pastarosios yra didesnès už patinus ir pateles iš Kučiuliškès herpetologinio draustinio. Lyginant dešimties mènesių patinèlių ir patelių morfometrinius rodiklius, pastebètas lytinis dimorfizmas, kada patelių šarvo aukštis, galvos plotis, karapaksas ir plastronas yra didesni nei patinų.

Raktažodžiai: Emys orbicularis, baliniai vèžliai, jaunikliai, morfometrija, Lietuva 